\title{
Rooting of jabuticabeira of cabinho mini-cuttings (Plinia trunciflora)
}

\author{
Cristiano Hossel1*, Américo Wagner Júnior², Jessica Scarlet Alves de Oliveira Hossel', \\ Kamila Cristina Fabiane', Adriana Dallago²
}

\footnotetext{
'Federal Technological University of Paraná, Pato Branco, Brazil

${ }^{2}$ Federal Technological University of Paraná, Dois Vizinhos, Brazi

*Corresponding Author, E-mail: cristianohossel@gmail.com
}

\begin{abstract}
The techniques of plant multiplication, when tested with native fruit trees, have proved to be limiting in several aspects, signaling that another technique should be tested, which might be recommended for the usage, especially in the jabuticaba trees which present a higher potential. The aim of this study was to test the usage of asexual propagation through minicuttings in jabuticabeira of cabinho according to the collection time, mini-cutting length and concentration of IBA. The work was performed at Federal Technological University of Paraná (UTFPR) - Campus Dois Vizinhos, Brazil. The samples were collected bimonthly. Mini-cuttings (6 or $8 \mathrm{~cm}$ ) with pair of leaves reduced to $25 \%$ of the original size were prepared. The mini-cuttings had their base immersed in liquid solution of indole-butyric acid $\left(0,3000\right.$ and $\left.6000 \mathrm{mg} \mathrm{L}^{-1}\right)$ and placed in plastic tubes containing commercial substratum. The experimental design was completely randomized with $2 \times 3 \times 6$ factorial (cutting length $\times$ IBA concentration $\times$ time of the year), with four replications, the experimental unit varied according to the number of shoots obtained. After 120 days of implementation of each collection, the parameters rooting and callogenesis (\%), average number of roots per mini-cutting and average root length were evaluated. After 60 days the survival of post-planting rooted mini-cuttings was evaluated. It is recommended that for the jabuticabeira of cabinho, the collection period for propagation through mini-cuttings should be in August.
\end{abstract}

Keywords: Plinia trunciflora (DC) Berg, native fruit trees, propagating plants

Introduction

The jabuticaba trees, belonging to the Myrtaceae family, are comprehended in nine species, among which there is the jabuticabeira of cabinho [Plinia trunciflora (DC) Berg], which presents natural occurrence in the Southwestern Region of Paraná state (Danner et al., 201 lb) and altitude regions.

The economic potential, of this and from the remaining jabuticaba tree species, occurs primarily for its presenting of sensorial proprieties, which attract the in natura market and its usage for industrialization, with the processing of jellies, sweets, ice-creams, fermented beverages, among others (Corrêa et al., 2007, Rufino, 2008).
The jabuticabeira of cabinho presents, as its main multiplication method, the seminiferous propagation, also utilized for the seedling production in the implantation of commercial orchards (Danner et al., 2011a), even with the limitation of the juvenile stage, which might variate from 8 to 12 years, and genetic variability.

Furthermore, one of the great challenges found in the seed propagation of the jabuticaba tree lies in the fact that these are classified as recalcitrant, rapidly losing their viability with the desiccation, even keeping them in controlled conditions of temperature and humidity (Hossel et al., 2013).

Based in these difficulties found as to the 
sexual propagation, several works ought to obtain an adequate protocol for seedling production through asexual propagation, such as through cuttings (Sasso et al., 2010b, Casagrande JR et al., 2000) and air layering (Danner et al., 2006, Cassol et al., 2015), which presented yet unsatisfactory results, and through grafting (Sasso et al. 2010a, Franco et al. 2010), which, in spite of the most promising results, presents the disadvantage of a longer period for seedling obtainment and the late-acting self-incompatibility, occurring in field.

Due to the difficulties found in the asexual propagation of the jabuticaba tree through the already utilized techniques, the mini-cuttings technique could be tested, being already commonly utilized in commercial manner for Eucalyptus sp. (Brondani et al., 2010), species belonging to the same family, and also successfully with cattley guava and guava (Altoé et al., 2011).

In this perspective, the aim of this work was to test the usage of asexual propagation through mini-cuttings in jabuticabeira of cabinho (Plinia trunciflora), according with the collection time, mini-cutting length and concentration of IBA.

\section{Material and Methods}

The work was performed in the Teaching

and Research Unit of Production Research of Horticulture Seedlings, of the Federal Technological University of Paraná (UTFPR) Campus Dois Vizinhos, PR.

For the performing of the experiment were utilized mother plants originated from jabuticabeira of cabinho (Plinia trunciflora) seeds with two years of age.

The mother plants were planted in plastic vessels (4L) in April of 2014, containing MecPlant ${ }^{\mathrm{B}}$ substratum and transferred to nursery with a $50 \%$ shadowing screen, receiving irrigation twice a day, with duration of 30 minutes.

Next to that, coppicing was performed in the shoot part, $10 \mathrm{~cm}$ high from the base, to stimulate the growth of the mother plants. In this manner, the garden was constituted by 100 mother plants, in which monthly fertilizations and daily use of aspersion irrigation were adopted, aiming the full vegetative development.
The monthly fertilization of the ministumps was performed with N-P-K (10-20-20) in the amount of $2 \mathrm{~g}$ per vessel, placed in the edge of the vessels, in contact with the substratum.

When the buddings originated from the coppiced seedlings reached a $10 \mathrm{~cm}$ height (August), the collection was performed, proceeding with such operation every two months, removing and preparing in herbaceous mini-cuttings, whose lengths were of 6 or $8 \mathrm{~cm}$, with the presence of a pair of leaves reduced to $25 \%$ of the original size.

The collections were performed in different times, every two months, namely in February, April, June, August, October and December.

At the removal of the mini-cuttings, these were kept in water buckets to avoid oxidation. The mini-cuttings had their base $(2 \mathrm{~cm})$ immersed (10s) in liquid solution of indole-butyric acid (IBA), in the concentrations of 0,3000 and $6000 \mathrm{mg} \mathrm{L}^{-1}$ and, following that, placed in tubes containing MecPlant ${ }^{\circledR}$ commercial substratum. Later, they were kept in climatized nursery, with relative humidity superior to $85 \%$ and average temperature of $25^{\circ} \mathrm{C}$.

In the IBA solution preparation, the acid was dissolved in absolute ethyl alcohol, being later diluted in distilled water until the desired concentration.

The experimental design was completely randomized, for each species, with a $2 \times 3 \times 6$ factorial (cutting length $x$ IBA concentration $x$ time of the year), with four replications, being the experimental unit variable in each collection time (February, April, June, August, October and December, with 30, 19, 5, 12, 15 and 19 minicuttings per experimental unit, respectively).

At 120 implantation days of each collection, the parameters rooting and callogenesis percentage, average number of radicles per mini-cutting and the average radicle length were evaluated.

For the average radicle length, the substratum was carefully removed through water washing, and the three larger radicles measured with a millimetric rule.

The rooted mini-cuttings were transplanted to vessels containing the MecPlant ${ }^{\circledR}$ 
commercial substratum, keeping them in nursery (50\% shadowing), containing irrigation through micro aspersion triggered twice a day. At 60 days after transplantation, the survival percentage of the rooted mini-cuttings was analyzed. The production of mini-cuttings in each time of the year was also evaluated, through the sum of the mini-cuttings production of the two tested sizes and division by the quantity of mother seedlings.

At the end of the experiment the survival percentage of the mother seedlings was analyzed.

The data from the evaluated variables were previously subjected to the Lilliefors normality test, proceeding with the transformations in $\sqrt{x+1}$ for the number of radicles per mini-cutting, radicles average length, and the transformation in $\arcsin \sqrt{x / 100}$ for callogenesis and survival.

With or without data transformation, these were subjected to variance analysis ( $p \leq$ $0,05)$ and to the Duncan test $(a=0,05)$ for the factors cutting length, time of the year and analysis of polynomial regression $(p \leq 0,05)$ for the IBA concentration in the mini-cutting experiment, with the usage of the Genes ${ }^{\circledast}$ and SANEST ${ }^{\circledR}$ softwares.

\section{Results and Discussion}

There was a significant interaction within the factors cutting length $x$ time of the year $x$ IBA concentration with the jabuticabeira of cabinho concerning the rooting (\%) (Table 1), between the IBA concentration $x$ time of the year for the average number of radicles per mini-cutting (Table 3), for the cutting length $x$ IBA concentration in the average length of radicles (Figure 1) and in the interaction cutting length $x$ time of the year in the variables average radicle length and survival post-transplantation (\%) (Table 4) and in the factors times of the year (Table 2) and IBA concentration (Figure 2) for callogenesis (\%).

It was verified that the mini-cuttings of $6 \mathrm{~cm}$, utilizing the concentrations of 0,3000 and $6000 \mathrm{mg} \mathrm{L}^{-1}$ of IBA, had the highest rooting rates in the month of August, comparing with the remaining months. The same superiority of this month for this variable was also found in the $8 \mathrm{~cm}$ mini-cuttings; however, such averages did not statistically differ from the months of October and December in the concentrations of 0 and 6000 $\mathrm{mg} \mathrm{L}^{-1}$ of IBA and in October with $3000 \mathrm{mg} \mathrm{L}^{-1}$ of IBA (Table 1).

In June, with $6 \mathrm{~cm}$ mini-cuttings, the highest rooting was obtained with $6000 \mathrm{mg} \mathrm{L}^{-1}$ of IBA, differently from the obtained in December, which had higher averages with 0 and $3000 \mathrm{mg}$ $\mathrm{L}^{-1}$ of IBA (Table 1).

By comparing these periods it might be supposed that due to June being a time of lower temperature, there was the need of utilizing a higher exogenous concentration of auxin for the obtainment of such superiority, a fact not demonstrated in December, a time of higher temperatures, whose higher IBA concentration might have caused a certain phytotoxicity, since that in such period the metabolic activities of the vegetal are found to be more accelerated, allowing active differentiation and development. In this manner, it might work for explaining the superiority obtained in the lower utilized concentrations of IBA in the mini-cuttings of lower length.

Danner et al. (2006), analyzing the propagation of Plinia cauliffora through air layering in the months of August, October, December and May, with the application of 0 , 4000 and $6000 \mathrm{mg} \mathrm{L}^{-1}$ of IBA, observed that for the obtainment of rhizogenesis in August, a time near to July without the application of such regulator, there was no formation of radicles, a fact not kept in December, when a rooting near to $70 \%$ was possible even without the usage of IBA.

In this manner, it might be said that the jabuticabeira of cabinho, for the emission of radicles, necessarily needs the exogenous application of IBA.

On the other hand, in December, with 8 $\mathrm{cm}$ mini-cuttings, the rooting superiority lied in the concentrations of 0 and $6000 \mathrm{mg} \mathrm{L}^{-1}$ of IBA (Table 1). Since it concerns higher length mini-cuttings, which might consequently present a higher $\mathrm{C} / \mathrm{N}$ relation, the intermediary concentration was harmful to the rhizogenesis process.

In the remaining epochs, with both minicutting lengths, the tested IBA concentrations had their averages statistically significant within 
each other as for the rooting (Table 1). This significance fact also occurred when comparing the rooting averages of the 6 and $8 \mathrm{~cm}$ minicuttings, within the tested times of the year and IBA concentrations.

On the other hand, in June, with $3000 \mathrm{mg}$
$\mathrm{L}^{-1}$ of IBA, the $8 \mathrm{~cm}$ mini-cuttings were statistically superior to the $6 \mathrm{~cm}$ mini-cuttings for rooting. An inverse fact for this same variable with the minicuttings treated with $6000 \mathrm{mg} \mathrm{L}^{-1}$ of IBA, in the same period, whose superiority lied in those with $6 \mathrm{~cm}$ length.

Table 1. Rooting (\%) of mini-cuttings of jabuticabeira of cabinho (Plinia trunciflora) according with the time of the year, length of mini-cuttings $(\mathrm{cm})$ and concentration of indole-butyric acid ( $\left.\mathrm{mg} \mathrm{L}^{-1}\right)$. Dois Vizinhos, 2017

\begin{tabular}{|c|c|c|c|c|c|c|}
\hline \multirow{4}{*}{$\begin{array}{c}\text { Time of the } \\
\text { Year }\end{array}$} & \multicolumn{6}{|c|}{ Cutting length (cm) } \\
\hline & \multicolumn{3}{|c|}{ Six } & \multicolumn{3}{|c|}{ Eight } \\
\hline & \multicolumn{3}{|c|}{ IBA concentration (mg L-1) } & \multicolumn{3}{|c|}{ IBA concentration $\left(\mathrm{mg} \mathrm{L}^{-1}\right)$} \\
\hline & 0 & 3000 & 6000 & 0 & 3000 & 6000 \\
\hline \multirow{2}{*}{ February } & $58,75 \mathrm{~b}(\mathrm{~A})$ & $71,25 \mathrm{~b}(\mathrm{~A})$ & $68,75 \mathrm{~b}(\mathrm{~A})$ & $57,50 \mathrm{~b}(\mathrm{~A})$ & $60,00 \mathrm{bc}(\mathrm{A})$ & $63,75 \mathrm{bc}(\mathrm{A})$ \\
\hline & $A^{*}$ & A & A & A & A & A \\
\hline \multirow{2}{*}{ April } & $32,95 \mathrm{~d}(\mathrm{~A})$ & $47,73 \mathrm{~cd}(\mathrm{~A})$ & $42,05 \mathrm{C}(\mathrm{A})$ & $28,33 \mathrm{C}(\mathrm{A})$ & $33,33 \mathrm{~d}(\mathrm{~A})$ & $35,00 \mathrm{~d}(\mathrm{~A})$ \\
\hline & $A$ & A & $A$ & A & A & A \\
\hline \multirow{2}{*}{ June } & $39,29 \mathrm{~cd}(\mathrm{~A})$ & $39,29 \mathrm{~d}(\mathrm{~B})$ & $71,43 \mathrm{~b}(\mathrm{~A})$ & $50,00 \mathrm{~b}(\mathrm{~A})$ & $58,33 \mathrm{bc}(\mathrm{A})$ & $50,00 \mathrm{~cd}(\mathrm{~B})$ \\
\hline & B & B & $A$ & A & A & $A$ \\
\hline \multirow{2}{*}{ August } & 93,75 a $(A)$ & 89,58 a $(A)$ & 89,58 a $(A)$ & 95,83 a (A) & 87,50 a $(A)$ & 89,59 a $(A)$ \\
\hline & A & $A$ & A & A & A & A \\
\hline \multirow{2}{*}{ October } & $65,00 \mathrm{~b}(\mathrm{~A})$ & $63,33 \mathrm{bc}(\mathrm{A})$ & $60,00 \mathrm{bc}(\mathrm{A})$ & 78,33 a $(A)$ & $75,00 \mathrm{ab}(\mathrm{A})$ & $75,00 \mathrm{ab}(\mathrm{A})$ \\
\hline & $A$ & $A$ & $A$ & A & A & $A$ \\
\hline \multirow{2}{*}{ December } & $56,72 \mathrm{bc}(\mathrm{B})$ & $63,04 \mathrm{bc}(\mathrm{A})$ & $44,57 \mathrm{C}(\mathrm{B})$ & 81,67 a $(A)$ & $55,00 \mathrm{C}(\mathrm{A})$ & 91,67 a $(A)$ \\
\hline & $A B$ & A & B & A & B & A \\
\hline
\end{tabular}

*Averages followed by the same lowercase letter on the column [time of the year (IBA concentration x length of mini-cuttings)], uppercase on the line [IBA concentration (time of the year xlength of mini-cuttings)] and uppercase in parentheses [length of mini-cuttings (time of the year x IBA concentration)] do not differ within each other, by Duncan's test $(a=0,05)$. ${ }_{* *}^{*} \mathrm{VC}$ (Variation coefficient).

It might be explained due to the higher mini-cuttings presenting of a greater amount of vegetal material, supporting the absorption of higher IBA concentrations without damage occurrence to the cells, where smaller cuttings might decrease the rooting as a consequence of phytotoxicity in the vegetal material.

In December, without IBA utilization, the $8 \mathrm{~cm}$ mini-cuttings were superior to those of 6 $\mathrm{cm}$ in the rooting process (Table 1). It might have occurred since they presented higher reserve amounts, important for metabolic support, such as found by Pizzatto et al. (2011) in cuttings of hibiscus.

As for the presence of calluses in the base of the jabuticabeira of cabinho mini-cuttings, the superiority was obtained in the month of April, followed by February, December, October, August and June, with this last month presenting the lowest result. The April superiority might be related to the milder temperatures of this month, reducing the mini-cuttings water loss for the environment and, at the same time, allowing a satisfactory metabolism for differentiation.

It might be said that this monthly emission behavior until the lowest percentage of minicuttings with calluses had a direct relation with the temperature behavior of the environment, with a higher production in the hotter months, lowering with temperature reduction, since that such environmental characteristic controls the reaction rate of the metabolic reactions in the vegetal.

The same result was found by Ferreira et al. (2010) in Sapium glandulatum (Vell.) mini-cuttings, when the months with lower temperatures resulted in the decrease of calluses production, what might have likely occurred through the temperature decrease.

Furthermore, the months with higher production of callused mini-cuttings had no relation with the same behavior for the rooting of these same mini-cuttings (Tables 1 and 2), being, in this manner, the presence of calluses an undesirable thing, since that competition is supposed in the consumption of photoassimilates, necessary for both differentiation processes.

The number of radicles per mini-cutting of jabuticabeira of cabinho in the concentration of $0 \mathrm{mg} \mathrm{L}^{-1}$ of IBA presented statistically superior 
averages in the months of February, August, October and December. A similar result occurred in the concentration of $6000 \mathrm{mg} \mathrm{L}^{-1}$ of IBA, differing only by the replacement of the highest statistical average from August to June. On the other hand, with the usage of $3000 \mathrm{mg} \mathrm{L}^{-1}$ of IBA, it was only possible to obtain superiority in the months of February and October (Table 3).

Table 2. Callogenesis (\%) of jabuticabeira of cabinho mini-cuttings (Plinia trunciflora) according with the time of the year. Dois Vizinhos, 2017

\begin{tabular}{cc}
\hline Time of the year & Callogenesis (\%) \\
\hline February & $8,94 \mathrm{~b}^{*}$ \\
April & $19,63 \mathrm{a}$ \\
June & $0,10 \mathrm{~d}$ \\
August & $1,91 \mathrm{C}$ \\
October & $2,29 \mathrm{C}$ \\
December & $2,48 \mathrm{C}$ \\
\hline VC (\%)** & 71,76 \\
\hline Averages tollowed by the same letter do not ditfer within each other by Duncan's lest $(\mathrm{a}=0,05)$. *ve \\
(Variation coefficient)
\end{tabular}

Table 3. Average number of radicles per mini-cutting of jabuticabeira of cabinho (Plinia trunciflora) according with the time of the year and concentration of indole-butyric acid $\left(\mathrm{mg} \mathrm{L}^{-1}\right)$. Dois Vizinhos, 2017

\begin{tabular}{|c|c|c|c|}
\hline \multirow{2}{*}{$\begin{array}{c}\text { Time of the } \\
\text { year }\end{array}$} & \multicolumn{3}{|c|}{ Concentration of Indole-butyric Acid ( $\left.\mathrm{mg} \mathrm{L}^{-1}\right)$} \\
\hline & 0 & 3000 & 6000 \\
\hline February & 1,78 a $A^{*}$ & $1,91 \mathrm{ab} A$ & $1,73 \mathrm{ab} A$ \\
\hline April & $1,27 \mathrm{~b} A$ & $1,18 \mathrm{~d} A$ & $1,25 \subset \mathrm{A}$ \\
\hline June & $1,18 \mathrm{~b} \mathrm{C}$ & 1,62 bcd $B$ & 1,97 a A \\
\hline August & 1,65 a A & $1,54 \mathrm{~cd} \mathrm{~A}$ & $1,57 \mathrm{~b} \mathrm{~A}$ \\
\hline October & 1,76 a $A$ & 2,03 a A & $1,69 \mathrm{ab} A$ \\
\hline December & 1,67 a A & $1,63 \mathrm{bc} \mathrm{A}$ & $1,77 \mathrm{ab} A$ \\
\hline $\mathrm{VC}(\%)^{* *}$ & \multicolumn{3}{|c|}{6,44} \\
\hline
\end{tabular}

When analyzing such results, it was verified that in both tested concentrations, the months with similarity in the superiority were February and October, a fact that might also be related to the behavior of the metabolic activities of the minicuttings favored by the higher temperatures, providing higher cell differentiation for the formation of radicles.

However, when comparing such IBA concentrations in each collection month, only June presented differences in the averages, with superiority for $6000 \mathrm{mg} \mathrm{L}^{-1}$ of IBA (Table 3).

This also demonstrates the favorable effect and the need for this auxin, in the higher concentration, to stimulate the increment in radicles production in periods of lower temperatures.

Oliveira et al. (2015), in cuttings of "ipêroxo" (Handroanthus impetiginosus), observed that the IBA application did no interfere in the results in a significant manner. Nevertheless, the highest IBA concentration (8000 $\mathrm{mg} \mathrm{L}^{-1}$ ) provided higher number of roots per mini-cutting, being possible to conclude that the application of exogenous auxin in cuttings provides the increase in the quantity of roots, until reaching a maximum point, in which phytotoxicity begins to occur.

This same differentiated behavior in June, and similarity behavior in the remaining months, was also observed for the length of radicles. However, comparing both lengths, it was demonstrated that the usage of larger mini-cuttings favored the obtainment of more elongated radicles (Table 4).

As in June the metabolic activities tend to decrease, the usage of larger mini-cuttings might have favored for providing a higher amount of reserves (carbon source) needed for allowing a satisfactory radicle growth.

When comparing results within each mini-cutting length in the collection months, it was verified that with $6 \mathrm{~cm}$, the higher averages were in February, August and December, and, with $8 \mathrm{~cm}$, in June, August and December. For both lengths, April and October presented the lowest averages for this variable (Table 4). 
Table 4. Average length of radicles $(\mathrm{cm})$ and Survival (\%) of jabuticabeira of cabinho mini-cuttings (Plinia trunciflora) according with the time of the year and length. Dois Vizinhos, 2017

\begin{tabular}{|c|c|c|}
\hline \multicolumn{3}{|c|}{ Average length of radicles $(\mathrm{cm})$} \\
\hline \multirow{2}{*}{$\begin{array}{c}\text { Time of the } \\
\text { year }\end{array}$} & \multicolumn{2}{|c|}{ Mini-cuttings length (cm) } \\
\hline & 6 & 8 \\
\hline February & $6,85 a b A^{*}$ & 6,94 a $A$ \\
\hline April & $4,70 \mathrm{C} \mathrm{A}$ & $4,64 \mathrm{~b} \mathrm{~A}$ \\
\hline June & $4,56 \subset B$ & 6,46 a $A$ \\
\hline August & $6,53 \mathrm{ab} A$ & 6,24 a $A$ \\
\hline October & $5,83 \mathrm{~b}$ A & $4,84 \mathrm{~b} \mathrm{~A}$ \\
\hline December & 7,18 a $A$ & 7,08 a $A$ \\
\hline $\mathrm{VC}(\%)^{* *}$ & \multicolumn{2}{|c|}{22,81} \\
\hline \multicolumn{3}{|c|}{ Survival (\%) } \\
\hline \multirow{2}{*}{$\begin{array}{c}\text { Time of the } \\
\text { year }\end{array}$} & \multicolumn{2}{|c|}{ Mini-cuttings length (cm) } \\
\hline & 6 & 8 \\
\hline February & 99,30 a $A^{*}$ & $97,54 \mathrm{bc} A$ \\
\hline April & 97,37 a B & 100,00 a A \\
\hline June & 99,32 a $A$ & 100,00 a $A$ \\
\hline August & 98,82 a $A$ & $94,75 \mathrm{C} \mathrm{A}$ \\
\hline October & 98,97 a A & $99,07 \mathrm{abc} A$ \\
\hline December & 96,88 a A & $99,79 \mathrm{ab} A$ \\
\hline $\mathrm{VC}(\%)^{* *}$ & & \\
\hline
\end{tabular}

It is supposed that such responses might have relation with the behavior already reported by Dotto (2016) for the jabuticaba tree, in which such fruiter presents growth outbreaks, being, in determined periods, directed to elongation, and, in others, to cell differentiation.

This average radicle length of jabuticabeira of cabinho mini-cuttings with six centimeters presented a growing linear behavior with the increase in the IBA concentrations applied. The same did not occur in those of 8 $\mathrm{cm}$, whose behavior turned to be quadratic with a point of maximum concentration of $2500 \mathrm{mg} \mathrm{L}^{-1}$ of IBA $(6,23 \mathrm{~cm})$ (Figure 1), being possible to affirm that from this point the IBA usage damaged the obtainment of a higher radicle elongation.

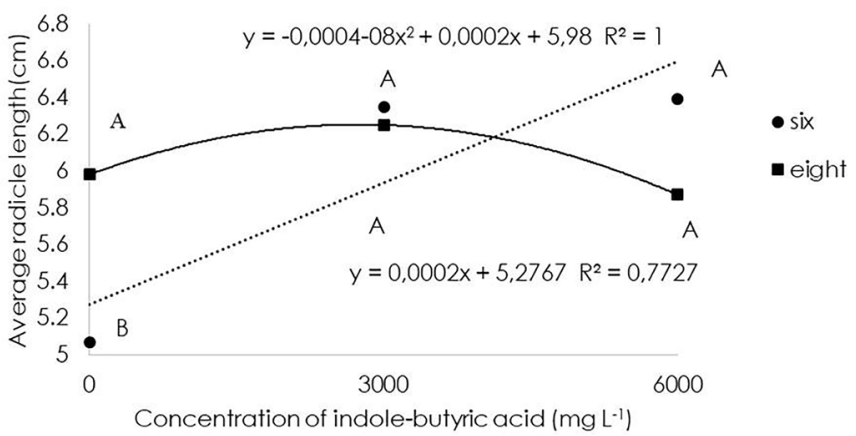

Figure 1. Average radicle length of jabuticabeira of cabinho minicuttings (Plinia trunciflora) according with the mini-cuttings length and the concentration of indole-butyric acid (IBA). Dois Vizinhos, 2017

Oliveira et al. (2015), with $5 \mathrm{~cm}$ cuttings of "ipê-roxo" (Handroanthus impetiginosus) verified that the increase in the IBA concentration provided increment in the radicle length, which might have occurred due to the activation of the expansins responsible for the elongation of the cell walls. The expansins are proteins, which rely on the action of the auxins over the $\mathrm{H}^{+}$- ATPase proteins of the plasmatic membrane for their activation (Pacheco et al., 2008).

However, such effect is provided for each species until a certain point, from which phytotoxicity emerges, as demonstrated in the 8 cm mini-cuttings (Figure 1).

The callogenesis percentage per mini-cutting of jabuticabeira of cabinho also presented a quadratic behavior, however, with a point of minimal concentration of $3333 \mathrm{mg} \mathrm{L}^{-1}$ of 
IBA $(2,97 \%)$ (Figure 2). In this manner, it was verified that when IBA was not utilized, a higher calluses production was induced in the base, what might be related to the targeting for the induction of the endogen auxin, aiming the healing of the material and not rhizogenesis.

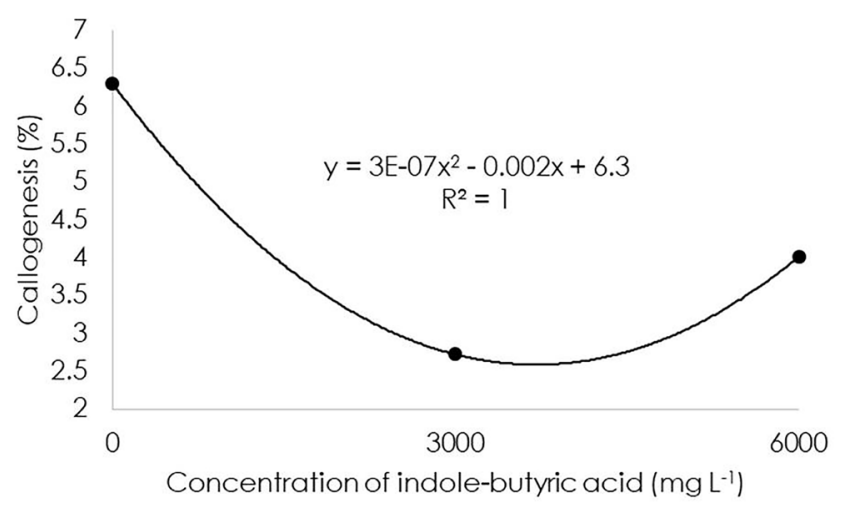

Figure 2. Callogenesis (\%) of the jabuticabeira of cabinho mini-cuttings (Plinia trunciflora) according with the concentration of indole-butyric acid (IBA). Dois Vizinhos, 2017

In Table 1, it was verified that the rooted mini-cuttings of six centimeters, after transplantation, presented statistical similarity of survival in the different tested times of the year. The same did not occur for those of $8 \mathrm{~cm}$, having superiority in April, June, October and December.

Nevertheless, in this length $(8 \mathrm{~cm})$, the lower average months had results from 94 to $97 \%$.

This demonstrates, generally, that independently of the superiority for one or another variable, the mini-cutting technique for the jabuticabeira of cabinho also turns out to promising for the obtainment of clones.

On Figure 3, it was possible to verify that the highest number of mini-cutting production per seedling of jabuticabeira of cabinho occurred in February $(6,0)$, followed by April and December $(4,5)$, epochs which comprehend the highest temperatures and insolation periods, consequently increasing the metabolism of plants and the production of photoassimilateds, favoring cell differentiation and late formation of new buddings.

At the end of the collections performed in the mother seedlings of jabuticabeira of cabinho for the obtainment of the mini-cuttings, it was seen that $91 \%$ of these were alive and in conditions to keep providing propagative material.

Furthermore, it might be noted that, although June presented the lowest number of buddings for usage as mini-cuttings, all times of the year allowed to collect material for asexual propagation of this fruiter (Figure 3), revealing, along with the results obtained for rooting and radicle growth, that such technique is promising and might be utilized for the obtainment of clonal seedlings of this fruiter.

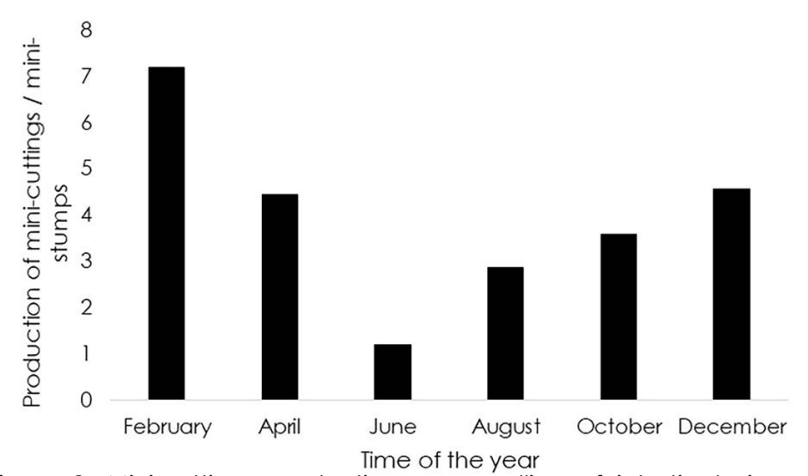

Figure 3. Mini-cuttings production per seedling of jabuticabeira of cabinho (Plinia trunciflora) in each time of the year. Dois Vizinhos, 2017 


\section{Conclusion}

It is recommended that for the jabuticabeira of cabinho (Plinia trunciflora) the collection period for propagation through minicutting must be in August, without the usage of IBA.

\section{References}

Altoé, J.A., Marinho, C.S., Terra, M.I.S., Barroso, D.G. 2011. Propagação de araçazeiro e goiabeira via miniestaquia de material juvenil. Bragantia 70(2): 312-318.

Brondani, G.E., Wendling, I., Grossi, F., Dutra, L.F., Araujo, M.A. 2010. Miniestaquia de Eucalyptus benthamii × Eucalyptus dunnii: (II) sobrevivência e enraizamento de miniestacas em função das coletas e estações do ano. Ciência Florestal 20(3): 453-465.

Casagrande Jr, J.G., Dutra, L.F., Tonietto, A., Nachtigal, J.C., Strelow, E. 2000. Efeito do estiolamento de ramos e do IBA no enraizamento de estacas herbáceas de jabuticabeira. Revista Brasileira De Agrociência 6(1): 24-26.

Cassol, D.A., Wagner Júnior, A., Pirola, K., Dotto, M., Citadin, I. 2015. Embalagem, época e ácido indolbutírico na propagação de jabuticabeira por alporquia. Revista Brasileira de Fruticultura, 37(1): 267-272.

Corrêa, M.O.G., Pinto, D.D., Ono, E.O. 2007. Análise da atividade respiratória em frutos de jabuticabeira. Revista Brasileira de Biociências, 5(supl.2): 831-833.

Danner, M. A., Citadin, I., Sasso, S.A.Z., Ambrosio, R., Wagner Júnior, A. 2011 la. Armazenamento a vácuo prolonga a viabilidade de sementes de jabuticabeira. Revista Brasileira de Fruticultura 33(1): 246-252.

Danner, M.A., Citadin, I., Fernandes Junior, A.A., Assmann, A.P., Mazaro, S.M., Donazzolo, J., Sasso, S.A.Z. 2006. Enraizamento de jabuticabeira (Plinia trunciflora) por mergulhia aérea. Revista Brasileira de Fruticultura 28(3): 530-532.

Danner, M.A., Citadin, I., Sasso, S.A.Z., Sachet, M.R., Malagi, G. 2011 b. Modo de reprodução e viabilidade de pólen de três espécies de jabuticabeira. Revista Brasileira de Fruticultura 33(2): 345-352.

Dotto, M. 2016. Desenvolvimento de Mudas e de Plantas de Plinia jabuticaba de acordo com a intensidade luminosa. $112 \mathrm{f}$. (Tese de Doutorado) - Universidade Tecnológica Federal Do Paraná, Pato Branco, Brazil.

Ferreira, B.G.A. Ribas, K.C.Z., Wendling, I., Koehler,
H.S., Nogueira, A.C. 2010. Miniestaquia de Sapium glandulatum (Vell.) Pax com o uso de ácido indol butírico e ácido naftaleno acético. Ciência Florestal 20(1): 19-31.

Franco, L.R.L. Silva, J.F., Maia, V.M., Lopes, P.S., Amorim, I.J.F., Mizobutsi, E.H. 2010. Sobrevivência e crescimento inicial de mudas de jabuticabeiras 'Açu' e 'Sabará' submetidas a dois tipos de enxertia. Revista Ceres 57(4): 535-538.

Hossel, C., Oliveira, J.S.M.A., Fabiane, K.C., Wagner Júnior, A., Citadin, I. 2013. Conservação e teste de tetrazólio em sementes de jabuticabeira. Revista Brasileira de Fruticultura 35(1): 255-261.

Oliveira, T.P.F., Barroso, D.G., Lamônica, K.R., Carvalho, V.S., Oliveira, M.A. 2015. Efeito do ácido indol-3-butírico (IBA) no enraizamento de miniestacas de ipê-roxo (Handroanthus heptaphyllus Mattos). Ciência Florestal 25(4): 1043-1051.

Pacheco, J.P., Franco, E.T.H. 2008. Substratos e estacas com e sem folhas no enraizamento de Luehea divaricata Mart. Ciência Rural 38(7): 1900-1906.

Pizzatto, M., Wagner Júnior, A., Luckmann, D., Pirola, K., Cassol, D.A., Mazaro, S.M. 2011. Influência do uso de IBA, época de coleta e tamanho de estaca na propagação vegetativa de hibisco por estaquia. Revista Ceres 58(4): 487492.

Rufino, M.S.M. 2008. Propriedades funcionais de frutas tropicais brasileiras não tradicionais. $263 \mathrm{f}$. (Tese de Doutorado) - Universidade Federal Rural do Semi-Árido, Mossoró, Brazil.

Sasso, S.A.Z., Citadin, I., Danner, M.A. 2010 a. Propagação de Jabuticabeira por enxertia e alporquia. Revista Brasileira de Fruticultura 32(2): 571-576.

Sasso, S.A.Z., Citadin, I., Danner, M.A. 2010 b. Propagação de jabuticabeira por estaquia. Revista Brasileira de Fruticultura 32(2): 577-583. 